\title{
PENDUGAAN VOLUME, POTENSI DAN DOMINASI JENIS BIDARA LAUT (Strychnos ligustrina Blume.) SEBAGAI BAHAN BAKU OBAT DI BALI BARAT
}

\author{
(The Estimation of Volume, Potency and Domination Type of Strychnos ligustrina \\ as Raw Materials Drugs in West Bali)
}

\author{
IWayan Widhiana Susila!
}

\begin{abstract}
Strychnos ligustrina Blume wood products have economic value as glass raw materials for healthy. The study aims to obtain tree volume estimation, wood potential and Bidara laut species dominance in the West Bali National Park. Data was collected by census for tree volume modeling activities and randomly for analysis of species vegetation using a $20 \mathrm{~m} \times 20 \mathrm{~m}$ plot. Plots are placed continuously forming a path, 2 path or 20 plots at each location. The volume estimation model at the height of the stem I branch diameter of $5 \mathrm{~cm}$ and the height of the base of the crown is $V=-0.017+0.004 \mathrm{D}$, where $V=$ wood volume $(\mathrm{m} 3$ / tree) and $D=$ diameter $(\mathrm{cm})$. This volume model only applies to tree diameters ranging from $5.0-15.0 \mathrm{~cm}$ in the West Bali NP area. This study revealed that potency Of Bidara Laut are $4.7 \mathrm{m3} / \mathrm{ha}$, with densities at each stand level are II 56 seedlings/ha, 172 saplings/ha, 38 poles/ha and 8 trees/ha. Three tree species in West Bali National Park that have the highest importance value index are Schoutenia ovata, Croton argiratus and Strychnos ligustrina.
\end{abstract}

Keywords : Strychnos ligustrina Blume, estimation model, wood product, West Bali

\begin{abstract}
ABSTRAK
Produk kayu bidara laut (Strychnos ligustrina Blume.) mempunyai nilai ekonomis sebagai bahan baku gelas untuk kesehatan. Penelitian bertujuan memperoleh penduga volume pohon, potensi kayu dan dominasi jenis Bidara Laut di Kawasan Taman Nasional Bali Barat. Pengumpulan data dilakukan secara sensus untuk kegiatan penyusunan model volume pohon dan secara random untuk analisis vegetasi jenis dengan menggunakan petak ukur $20 \mathrm{~m} \times 20 \mathrm{~m}$. Petakpetak ukur diletakkan secara kontinyu membentuk jalur, 2 jalur atau 20 petak ukur pada setiap lokasi. Model penduga volume sampai tinggi pohon pada diameter ujung batang/cabang $5 \mathrm{~cm}$ dan tinggi pangkal tajuk adalah $\mathrm{V}=-0,0 \mathrm{I7}+$ $0,004 \mathrm{D}$, dimana $V=$ volume kayu $\left(\mathrm{m}^{3} /\right.$ pohon) dan $\mathrm{D}=$ diameter/dbh $(\mathrm{cm})$. Model volume ini hanya berlaku pada selang diameter pohon antara 5,0 - 15,0 cm di kawasan TN Bali Barat. Hasil penelitian menunjukkan bahwa potensi kayu bidara laut di kawasan TN Bali Barat adalah 4,7 $\mathrm{m}^{3} / \mathrm{ha}$, dengan kerapatan setiap tingkat tegakannya adalah semai I I 56 tanaman/ha, pancang 172 tanaman/ha, tiang 38 tanaman/ha dan tingkat pohon 8 tanaman/ha. Tiga jenis pohon di TN Bali Barat yang memiliki indeks nilai penting tertinggi berturut-turut adalah Schoutenia ovata, Croton argiratus dan Strychnos ligustrina.
\end{abstract}

Kata Kunci : Bidara laut, model dugaan, produk kayu, Bali Barat

\author{
Author Institution $\quad$ : IPeneliti Balai Penelitian dan Pengembangan Teknologi Hasil Hutan Bukan Kayu, Jalan Dharma \\ Bhakti No. 7-Po Box 1054, Ds. Langko, Kec. Lingsar Lombok Barat - NTB 8337I, Telp. (0370) \\ 6573874, Fax. (0370) 657384I \\ Koresponding Author : Tel.081999058848; Email: I bpkmataram@yahoo.co.id; widhianasusila@gmail.com \\ Articel History : Received 09 October 2019; received in revised from I3 April 2020; accepted 19 April 2020;Available \\ online since 30 April 2020
}




\section{PENDAHULUAN}

Bidara laut (Strychnos ligustrina BI) merupakan salah satu jenis tanaman penghasil hasil hutan bukan kayu (HHBK) yang cukup potensial sebagai bahan baku obat-obatan di Bali dan Nusa Tenggara Barat (NTB). Di NTB terutama di Kabupaten Bima dan Dompu terkenal dengan nama kayu songga, sebaran alaminya banyak terdapat pada daerah tersebut. Sementara di Bali disebut kayu pait, yang potensi dengan sebaran alami di kawasan Taman Nasional Bali Barat (TNBB). Jenis Bidara Laut mengandung senyawa bahan obat seperti zat striknin, brusin dan alkaloid lainnya yang pada takaran tertentu dapat digunakan sebagai tonikum, obat demam, obat luka, dan lain-lain (Setiawan dan Rostiwati, 2014). Bidara laut merupakan pohon yang dapat mencapai diameter batang hingga $30 \mathrm{~cm}$ dengan tinggi rata-rata $12 \mathrm{~m}$, dan semua bagian dari pohon bidara laut terasa pahit dan yang paling pahit adalah bagian akarnya (Heyne, 1987).

Secara ekonomi produk kayu bidara laut dapat digunakan sebagai bahan baku pembuatan gelas untuk kesehatan. Nama lokal produk gelas dari bahan baku jenis tersebut adalah "Gelas Songga”. Produk gelas songga diusahakan oleh masyarakat dalam sekala industri rumah tangga, kebanyakan berdomisili di Kabupaten Dompu dan Bima, yang pasarnya sampai ke luar NTB. Manfaat produk gelasnya adalah hasil rendaman air gelas tersebut berkhasiat untuk mengobati beberapa penyakit seperti malaria, demam, penyakit kulit, gangguan sirkulasi darah, meredakan rasa sakit, merangsang sistem syaraf, menambah nafsu makan, menyegarkan kulit muka, membangkitkan nafsu makan, menyembuhkan sakit rematik (nyeri persendian), sakit perut, dan sebagai obat luar seperti bisul dan kurap (Hasan, et al, 201I, Setiawan dan Narendra, 20I2).

Pemanfaatan kayu bidara laut sebagai obat-obatan di NTB sudah pada tahap pemasaran, tetapi kebanyakan masih dalam bentuk bahan utuh tanpa pengolahan lebih lanjut. Bahan baku gelas songga adalah berupa kayu batangan bulat (jenis batang atau cabangnya) berukuran diameter $\geq 10 \mathrm{~cm}$ dengan panjang sortimen minimal $20 \mathrm{~cm}$. Sistem pemungutan bahan bakunya adalah masyarakat menebang pohon secara illegal yang sebagian besar berasal dari dalam kawasan hutan dan tanah negara yang tumbuh alami di Kabupaten Dompu dan Bima Sumbawa. Oleh karena itu, keberadaan potensi produk kayu bidara laut di habitatnya cenderung menurun karena belum ada regulasi mengenai pelestarian jenis tersebut. Kondisi ini dapat dibuktikan oleh banyaknya keluhan pengrajin pembuatan gelas songa di NTB mengenai langkanya bahan baku sehingga beberapa pengrajin gulung tikar (Maharani, et al, 20ll). Hasil survey potensi areal bekas tebangan bidara laut di Kabupaten Bima dan Dompu, menunjukkan jarang ditemukan pohon bidara laut dengan diameter batang (dbh) di atas $10 \mathrm{~cm}$ (Susila, 2013; 2016).

Sampai saat ini, belum tersedia data mengenai perkembangan potensi tanaman bidara laut, baik di NTB maupun di Bali. Kabupaten Dompu pernah menghasilkan produk kayu bidara laut dengan produksi 6 ton pada tahun 2004 (Dishut NTB, 2007). Perkembangan jenis-jenis HHBK lainnya seperti madu, gaharu, kemiri, bambu, aren, arang, asam, dan rotan pernah juga tercatat volume produksinya dari tahun 2000 - 2005 (Bappenas, 2006). Sampai Tahun 2016, belum ada informasi produksi dan potensi tanaman Bidara Laut di NTB, hanya tercatat produksi 4 
jenis HHBK lainnya, seperti rotan, bambu, madu dan kemiri (Dinas Lingkungan Hidup dan Kehutanan, 2017)

Di Provinsi Bali sebaran lokasi bidara laut sangat terbatas, tidak seperti sebarannya di NTB. Bidara laut hanya terdapat di Kecamatan Gerokgak, Kabupaten Buleleng, tepatnya di dalam kawasan Taman Nasional (TN) Bali Barat (Setiawan, et al, 20l3). Secara legal tanaman ini tidak pernah dimanfaatkan karena terbentur regulasi, namun pernah juga ditemukan bekas tebangan beberapa pohon (illegal logging) di lokasi yang berbatasan dekat dengan pantai selat Bali. Kondisi tegakannya sangat baik karena berada di dalam kawasan konservasi sehingga ekositemnya tidak terganggu. Lain halnya dengan keberadaan jenis ini di NTB, bidara laut yang tumbuh terutama pada tanah-tanah negara (di luar kawasan hutan) yang semuanya areal bekas tebangan yang kondisinya relatif rusak, namun regenerasi alam dari trubusan cukup tinggi yaitu rata-rata tumbuh lebih dari satu batang tunas pada setiap tunggak batang bidara laut (Susila, 2013 ; 2016). Terlepas dari status kawasan, untuk pemanfaatan jenis ini dalam hubungannya sebagai sumber bahan baku untuk pembuatan gelas dan bahan baku obatobatan lainnya, perlu dilakukan survey pada lokasi sebaran di dalam kawasan untuk mengetahui stok produksi kayu bidara laut di Bali. Dengan demikian, tujuan penelitian ini adalah menyusun model penduga volume pohon, dan mengetahui potensi tegakan dan dominasi jenis bidara laut di Kawasan Taman Nasional Bali Barat.

\section{METODE PENELITIAN}

\section{A. Lokasi dan Waktu Penelitian}

Penelitian dilakukan secara purposive sampling berdasarkan keberadaan bidara laut di kawasan Taman Nasional Bali Barat dengan lokasi di Teluk Terima, Banyuwedang dan Prapat Agung. Kegiatan pengumpulan data lapangan dilaksanakan dari bulan Mei sampai dengan November 2014.

\section{B. Penentuan Pohon Model Bidara Laut}

Pengumpulan data terhadap tanaman tingkat pohon dengan diameter batang $(\mathrm{dbh}) \geq$ $5 \mathrm{~cm}$ dilakukan secara sensus pada setiap lokasi. Parameter yang diukur pada kegiatan ini adalah diameter batang pohon setinggi dada (dbh) untuk tingkat pohon berdiameter $\geq 5$ $\mathrm{cm}$. Berdasarkan hasil sensus, kemudian secara proporsional dilakukan penentuan jumlah pohon model sebagai sampel untuk menduga volume pohon berdiri. Jumlah pohon model (terpilih) pada setiap kelas diameter ditentukan oleh sebaran populasi di lapangan dan dihitung dengan cara Newman-Keul proportional (Alder, 198I dalam Bustomi, et al, 2005), yaitu :

$$
n i=(N i / N) * n
$$

dimana :

ni $=$ jumlah pohon model pada setiap kelas diameter,

$\mathrm{Ni}=$ jumlah pohon pada kelas diameter ke $\mathrm{i}$ (i: $1,2 \ldots . .4)$,

$\mathrm{N}=$ total jumlah pohon (populasi amatan),

$\mathrm{n}=$ jumlah pohon model.

Parameter yang diukur pada setiap pohon model adalah :

- Diameter batang pohon (dbh) diukur I,3 m dari pangkal batang

- Tinggi pohon pada pangkal tajuk

- Tinggi pohon sampai pada diameter batang/cabang $\geq 5 \mathrm{~cm}$ (ukuran dimensi termanfaatkan)

- Keliling perseksi batang setiap panjang 30 $\mathrm{cm}$, mulai dari pangkal batang $(20 \mathrm{~cm}$ di atas tanah) sampai pada diameter batang dan atau semua cabang $\geq 5 \mathrm{~cm}$ (Gambar). 


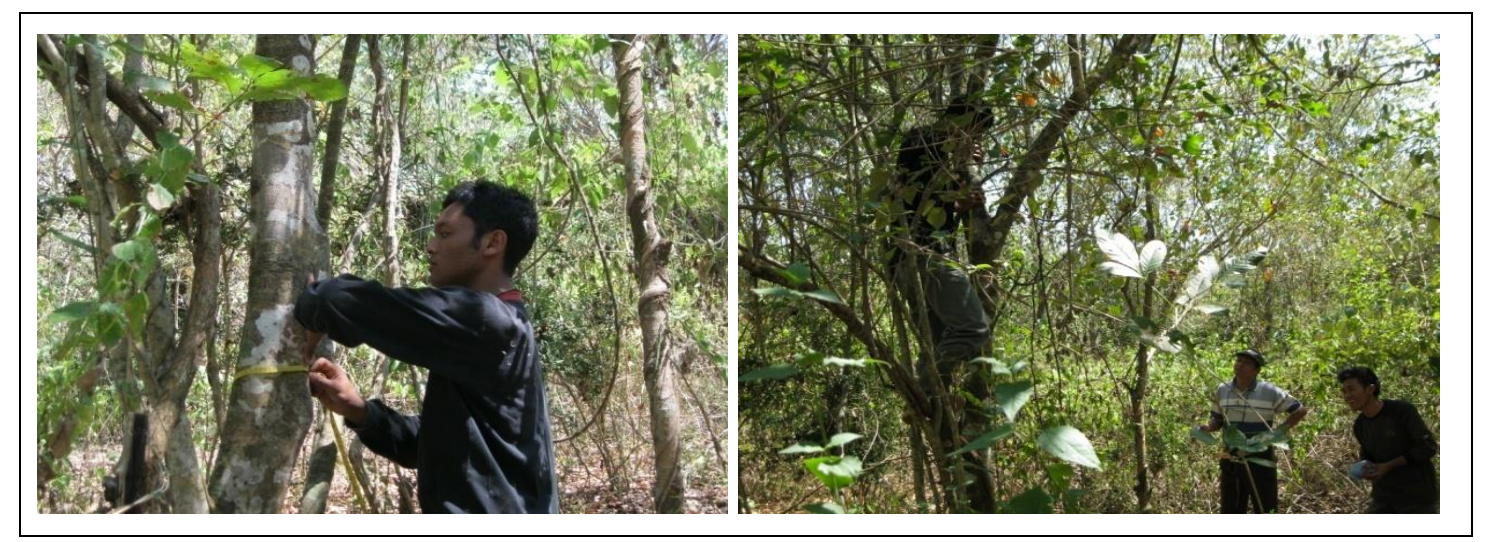

\section{Gambar I. Pengukuran keliling batang perseksi di TN Bali Barat Figure I. Stem perimeter measure on each section in National Park of West Bali}

\section{Analisis Vegetasi Bidara Laut}

Kegiatan analisa vegetasi untuk jenis bidara laut dilakukan untuk semua tingkatan vegetasi, yaitu tingkat anakan (seedling), pancang (sapling), tiang (pole) dan tingkat pohon. Sementara untuk jenis lainnya, hanya pada tingkat pohon yang berdiameter lebih dari 10 cm (Heddy, 2012). Petak contoh ukuran $20 \mathrm{~m}$ x $20 \mathrm{~m}$ sebanyak 10 plot diletakkan secara kontinyu sehingga membentuk jalur (Soerianegara \& Indrawan, 1988), dengan ulangan 2 jalur pada setiap lokasi di Banyuwedang, Teluk Terima, Prapat Agung I dan Prapat Agung II. Parameter yang diamati dan diukur pada setiap petak contoh adalah jumlah individu dan diameter setiap jenis.

\section{Analisis Data}

\section{Penyusunan model dugaan volume kayu}

Volume kayu pohon aktual merupakan jumlah volume setiap seksi dari pohon yang bersangkutan. Volume setiap seksi dihitung dengan rumus Smallian (Sumadi, et al, 2010) :

$$
V_{S}=\frac{B+b}{2} \times L
$$

Dimana, $V_{s}=$ volume seksi batang; $B=$ luas bidang dasar pangkal seksi; $\quad b=$ luas bidang dasar ujung seksi; dan $L=$ panjang seksi.

Sebelum penyusunan model dilakukan uji normalitas data melalui test shapiro-Wilk dan Kolmogorov-Smirnov atau test Skewness dan Kurtosis (Nurgiyantoro, et al, 2009). Jika tidak terdistribusi normal, maka perlu dilakukan identifikasi data dan penghapusan data pencilan pada frekuensi sebaran data tersebut supaya terdistribusi normal. Model dugaan produksi kayu bidara laut disusun dengan analisis regresi. Melakukan uji autokorelasi melalui hasil test Durbin-Watson, untuk mengetahui ada tidaknya korelasi pada variabel-variabel yang berpengaruh. Selanjutnya, melalui uji $\mathrm{F}$ pada anova untuk menguji linearitas model jika model yang disusun berbentuk persamaan regresi linear. Bentuk umum model persamaan regresi linear dengan satu dan dua variabel adalah sebagai berikut :

$\tilde{V}=a+b D$ (Simon, 2007 ; Curve Expert 1.3)

$\tilde{\mathrm{V}}=\mathrm{a}+\mathrm{b} \mathrm{D}+\mathrm{cT}$ (Simon, 2007; Curve Expert 1.3)

$\log \tilde{V}=\log a+b \log D+c \log T$ (Zewdie et al, 2012)

Dimana $: \tilde{V}=$ dugaan volume pohon bidara laut $\left(\mathrm{m}^{3}\right) ; \mathrm{D}=$ diameter batang setinggi dada $(\mathrm{cm})$; $\mathrm{T}=$ tinggi pohon pada ketinggian pangkal tajuk atau diameter batang/cabang $\geq 5 \mathrm{~cm} \quad(\mathrm{~m})$; a,b, c $=$ konstanta. 
Model regresi linear yang telah disusun, kemudian diperbandingkan dengan model regresi yang lain seperti model regresi power, logharitma, kuadratik dan eksponensial dengan melihat kesalahan baku, koefesien determinasi dan kesederhanaan model. Model-model regresi yang dicobakan dapat dinotasikan sebagai berikut :

- Model power : $\tilde{\mathrm{V}}=\mathrm{a} \mathrm{D}^{\mathrm{b}}$ (Brassard, et al, 20I I; Arevalo, et al, 2007)

- Model eksponensial $: \tilde{V}=a e^{b D}$ (Subedi and Sharma, 2012 : Curve Expert I.3)

- Model Logaritma : $\tilde{V}=\log a+b \log D$ (Curve Expert I.3)

- Model Kuadratik : $\tilde{V}=a+b D+c D^{2}$ (Turski, et al, 2008; Simon, 2007; Curve Expert 1.3)

Dimana : $\tilde{\mathrm{V}}=$ dugaan volume pohon; $\mathrm{D}=$ diameter batang setinggi dada (dbh); a,b, $\mathrm{c}=$ konstanta; $=2,7183$.

Uji validitas model volume didasarkan pada pertimbangan kecilnya persen galat baku (SE), simpangan agregatif (SA) dan simpangan rataan (SR). SE, SA dan SR dihitung dalam bentuk rumus sebagai berikut (Husch, 1963):

$\mathrm{SE}=$ Simpangan baku/rerata volume $\times 100 \%$ $\mathrm{SA}=(\Sigma \mathrm{VA}-\Sigma \mathrm{V}) / \Sigma \mathrm{VA} \times 100 \%$ $\mathrm{SR}=\Sigma(|\mathrm{VA}-\mathrm{V}| / \mathrm{VA}) / \mathrm{N} \times 100 \%$

Dimana $\mathrm{V}_{\mathrm{A}}=$ volume aktual; $\mathrm{V}=$ volume dugaan (menurut persamaan); dan $\mathrm{N}=$ jumlah pohon sampel.

Dalam menyusun model persamaan regresi yang menggunakan satu peubah diperkenankan simpangan baku maksimal 25 $\%$, sedangkan apabila menggunakan dua peubah diperkenankan SE maksimal $20 \%$ (Prodan, 1965). Sementara menurut Marcelino (1966) dalam Siswanto \& Wahjono (1996), menyatakan bahwa tingkat ketelitian model persamaan regresi dapat dilihat dari nilai SA dan SR yang lebih rendah dari $10 \%$ dan I \%.

\section{Perhitungan potensi tegakan}

Berdasarkan data yang diperoleh dari pengukuran lapangan dihitung kerapatan dan volume tegakan bidara laut pada tiap lokasi. Kerapatan tegakan dihitung berdasarkan jumlah tanaman $(\mathrm{N})$ per satuan luas (ha). Volume tegakan dihitung jumlah kubik kayu $\left(\mathrm{m}^{3}\right)$ per ha.

\section{Analisa vegetasi}

Indeks Nilai Penting (INP) pada tingkat pohon didekati melalui penjumlahan kerapatan relatif, frekuensi relatif dan dominasi relatif. Masing-masing indikator dapat dinotasikan sebagai berikut (Fachrul, 2007) :

$$
\begin{aligned}
& K=\frac{\text { Jumlah individu suatu jenis }}{\text { Luas total pengamatan }} \times 100 \% \ldots .[\mathrm{I}] \\
& \left.. K R=\quad \begin{array}{c}
\text { Kerapatan suatu jenis } \\
\text { Kerapatan seluruh jenis }
\end{array} \quad \times 100 \% \ldots . . .2\right] \\
& F=\frac{\text { Jumlah plot ditemukannya suatu jenis }}{\text { Total plot pengamatan }} \times 100 \% \ldots . . \text { [3] } \\
& F R=\frac{\text { Frekuuensi jenis }}{\text { Frekuensi seluruh jenis }} \times 100 \% . .[4] \\
& D=\frac{\text { Luas bidang dasar suatu jenis }}{\text { Luas total pengamatan }} \times 100 \% \ldots .[5] \\
& D R=\frac{\text { Dominasi suatu jenis }}{\text { Dominasi seluruh jenis }} \times 100 \% \text {......... [6] } \\
& I N P=K R+F R+D R \ldots \ldots \ldots \ldots \ldots \ldots \ldots \ldots \ldots[7]
\end{aligned}
$$

\section{HASIL DAN PEMBAHASAN}

\section{A. Model Dugaan Volume Kayu Bidara Laut}

Hasil identifikasi menunjukkan jumlah pohon berdiameter batang $\geq 5 \mathrm{~cm}$ pada 
seluruh lokasi sebanyak 2II pohon. Berdasarkan sebaran kelas diameter, jumlah pohon contoh yang dipilih sebanyak 120 pohon terdiri dari 42 pohon di Banyuwedang, 40 pohon di teluk Terima, dan 37 pohon di Prapat Agung (Tabel I). Sebaran kelas diameter diklasifikasikan dengan rentang 5,0 $7,5 \mathrm{~cm}$ sampai dengan $12,5-15,0 \mathrm{~cm}$. Penentuan rentang kelas diameter dimaksudkan untuk memudahkan identifikasi pengelompokkan individu pohon bidara laut di lapangan.

Tabel I. Sebaran diameter pohon bidara laut di Bali Barat

Table I.Tree diameter distribution of Strychnos ligustrina in West Bali

\begin{tabular}{ccccc}
\hline No. & $\begin{array}{c}\text { Kelas diameter } \\
\text { (Diameter classes) } \\
(\mathbf{c m})\end{array}$ & $\begin{array}{c}\text { Pohon } \\
\text { teridentifikasi } \\
\text { (Trees identified) }\end{array}$ & $\begin{array}{c}\text { Jumlah pohon (Number of tree) } \\
\text { pohon model di } \\
\text { lapangan (Model } \\
\text { trees in the field) }\end{array}$ & $\begin{array}{c}\text { Pohon model terpilih } \\
\text { (Selected model trees) }\end{array}$ \\
\hline I. & $5,0-7,5$ & 57 & 34 & 33 \\
2. & $7,5-10,0$ & 75 & 42 & 40 \\
3. & $10,0-12,5$ & 49 & 31 & 30 \\
4. & $12,5-15,0$ & 30 & 13 & 13 \\
\hline & Jumlah & $\mathbf{2 1}$ & $\mathbf{1 2 0}$ & $\mathbf{1 1 6}$ \\
\hline
\end{tabular}

Model-model yang dicoba untuk menduga volume kayu bidara laut (V) dengan menggunakan satu variabel yaitu diameter batang setinggi dada (D), dan dua variabel (D) dan tinggi pohon (T). Hasil uji normalitas data terhadap sebaran diameter tersebut, disajikan pada Tabel 2. Hasil test pertama signifikan $(P<0,05)$, dan yang kedua, nilai skewnes tidak memenuhi persyaratan sesuai yang diperkenankan. Jika nilai pertama signifikan atau yang kedua tidak memenuhi persyaratan (nilai rasio tidak berada antara rentangan -2 sampai +2) (Nurgiyantoro, et al, 2009), maka data diameter tersebut tidak terdistribusi secara normal.

Tabel 2. Pengujian normalitas data

Table 2. Data normaly examination

\begin{tabular}{lcc}
\hline \multicolumn{1}{c}{ Test } & Statistic & Sig. /Se* \\
\hline Shapiro-Wilk & 0,948 & 0,000 \\
\hline Kolmogorov-Smirnov & 0,115 & 0,001 \\
\hline Skewness & 0,548 & $0,225^{*}$ \\
\hline Kurtosis & $-0,575$ & $0,446^{*}$ \\
\hline
\end{tabular}

Setelah membuang data pencilan agar data tersebut terdistribusi normal, jumlah data tersisa sebanyak 8I ukuran diameter setinggi dada pohon bidara laut. Pada Tabel 3 dapat dilihat bahwa hasil test Shapiro-Wilk dan Kolmogorov-Smirnov adalah tidak signifikan
$(P>0,05)$ yang berarti data terdistribusi normal. Dipertegas lagi oleh hasil test Skewness dan Kurtosis, yaitu nilai rasionya 0,02 $(0,006 / 0,267)$ dan $-1,10(-0,582 / 0,529)$, yang termasuk dalam rentangan nilai antara - 2 sampai +2 . Data menyebar normal, dapat juga 
diperjelas melalui Gambar 2. Titik-titik yang berada sekitar garis lurus (Z-skor) menunjukkan bahwa sebaran ukuran diameter adalah normal (Gambar kiri). Gambar yang disebelahnya, terdapat garis horizontal lurus di tengah, kemudian titik-titik berada disekitar garis tersebut, yang berarti skor variabel yang bersangkutan (ukuran diameter) dinyatakan normal. Normalitas data memberikan keakuratan pendugaan model (Chen, et al, 2003).

Tabel 3. Pengujian normalitas data setelah menghapus pencilan data Table 3. Testing the data normality after deleting the data

\begin{tabular}{lcc}
\multicolumn{1}{c}{ Test } & Statistic & Sig. /Se* \\
\hline Shapiro-Wilk & 0,079 & 0,200 \\
\hline Kolmogorov-Smirnov & 0,988 & 0,634 \\
\hline Skewness & 0,006 & $0,267^{*}$ \\
\hline Kurtosis & $-0,582$ & $0,529^{*}$ \\
\hline
\end{tabular}

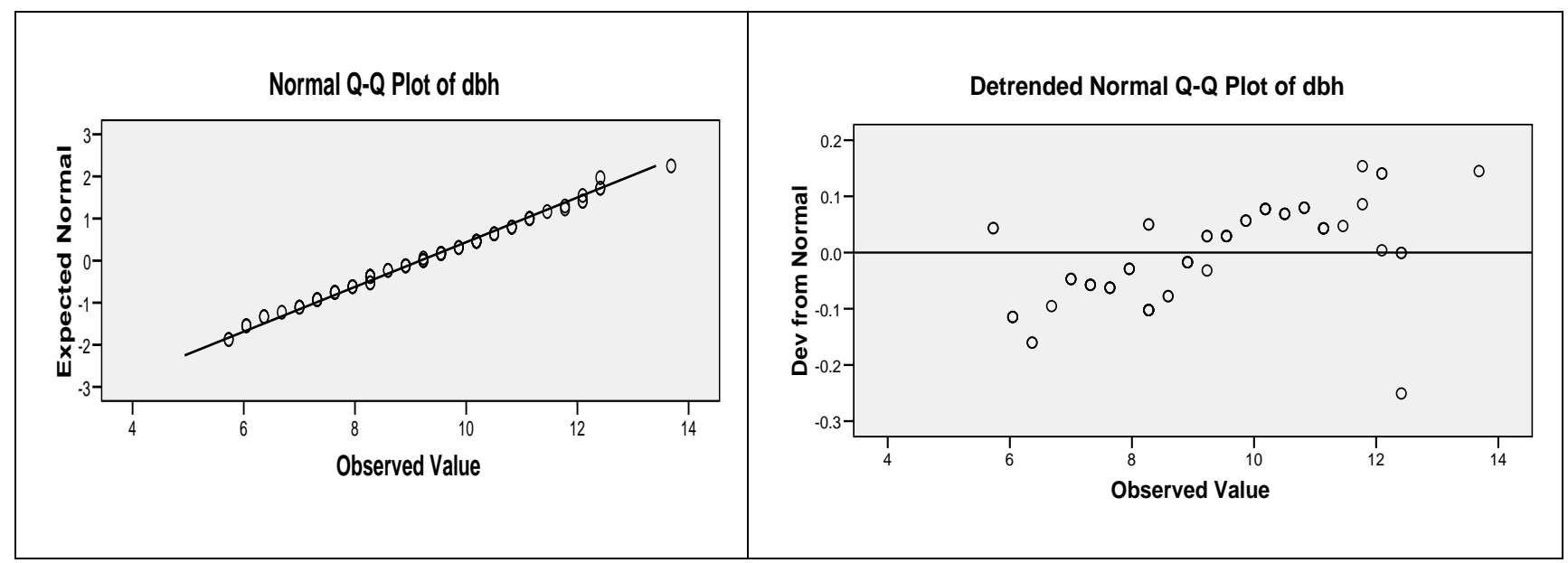

Gambar 2. Sebaran normal ukuran diameter pohon

Figure 2. Normal distribution of tree diameter size

\section{Model penduga volume sampai diameter ujung batang/cabang $5 \mathrm{~cm}$}

Berdasarkan variabel bebas yang tersedia, ada dua model persamaan regresi yang digunakan untuk menduga volume pohon bidara laut, yaitu menggunakan satu variabel (diameter pohon) dan dua variabel (diameter dan tinggi pohon). Hasil uji autokorelasi, output Durbin-Watson adalah I,645 (Tabel 4). Untuk menyimpulkannya perlu menggunakan Tabel Durbin-Watson dengan $\alpha=5 \%, k=2)$. Kriteria ujinya adalah : I) $\mathrm{d}<\mathrm{dl}$ atau $\mathrm{d}>4-\mathrm{dl}$, artinya ada autokorelasi, 2) du $<\mathrm{d}<4$ - du, artinya tidak ada autokorelasi, dan 3) $\mathrm{dl}<\mathrm{d}<$ du atau 4 $\mathrm{du}<\mathrm{d}<4$ dl, tidak ada kesimpulan (www.spssstatistik.com, 20I8). Berdasarkan tabel tersebut dan dan perhitungannya, nilainya termasuk $\mathrm{dl}<\mathrm{d}<\mathrm{du}$ yaitu autokorelasinya cenderung tidak dapat disimpulkan. 
Tabel 4. Pengujian autokorelasi, tingkat korelasi dan linearitas model dengan dua variabel

Table 4. Autocorrelation, correlation level and model linearity test with two variables

\begin{tabular}{lcc}
\hline \multicolumn{1}{c}{ Test } & -Statistic- & Table value/Sig. \\
\hline Durbin-Watson & $\mathrm{I}, 645$ & $\mathrm{I}, 5888(\mathrm{dl}), \mathrm{I}, 6898(\mathrm{du})$ \\
\hline Koefesien Korelasi $(\mathrm{r})$ & 0,614 & 0,000 \\
\hline Anova $(\mathrm{F})$ & 90,407 & 0,000 \\
\hline
\end{tabular}

Sehubungan dengan tidak jelasnya autokorelasi kedua variabel, maka perlu melihat tingkat korelasi antara kedua variabel tersebut. Sebaiknya menggunakan satu variabel untuk membentuk model regresi yang mempunyai korelasi yang relatif tinggi. Pada Tabel 4 dapat dilihat bahwa koefesien korelasi ( $r$ ) kedua variabel bebas sangat signifikan pada taraf nyata I \% $\left(0,6 \mid 4^{* *}\right)$. Oleh karena itu, untuk menduga volume pohon bidara laut sebaiknya menggunakan satu variabel bebas saja, yaitu diameter pohon (dbh) (Tabel 5). Disamping itu, tidak mungkin melakukan pengukuran tinggi pohon (T5) di lapangan, karena tingkat kesulitannya relatif tinggi. Pada Tabel 5 dapat dilihat bahwa model persamaan dengan satu variabel dibentuk sesuai dengan persyaratan, yaitu tidak ada autokorelasi, korelasi antar variabel sangat signifikan, dan hasil uji $F$ sangat signifikan sebagai petunjuk keabsahan model linear (linearitas model). Kesalahan baku (SE) hasil perhitungannya adalah $0,007 /$ rerata volume $x$ $100 \%=3,19 \%$. Berdasarkan hasil SE tersebut, terpenuhi lagi persyaratan sesuai dengan yang diperkenankan, yaitu dalam menyusun model persamaan regresi menggunakan satu peubah diperkenankan kesalahan baku maksimal $25 \%$ (Prodan, 1965).

\section{Tabel 5. Hasil test autokorelasi, tingkat korelasi, dan model regresi dengan satu variabel diameter}

Table 5. Autocorrelation, correlation level and model linearity test with one variable

\begin{tabular}{lcc}
\hline \multicolumn{1}{c}{ Test } & Statistic & Table value/Sig. \\
\hline Durbin-Watson & 2,003 & $\mathrm{I}, 6139(\mathrm{dl}), \mathrm{I}, 6639(\mathrm{du})$ \\
\hline Koefesien Korelasi $(\mathrm{r})$ & 0,867 & $0,000^{* *}$ \\
\hline Anova $(\mathrm{F})$ & $96,79 \mathrm{I}$ & $0,000^{* *}$ \\
\hline Model regresi & $\mathrm{V}=-0,017+0,004 \mathrm{dbh}$ & 0,007 (std error) \\
\hline
\end{tabular}

Lebih lanjut, model yang sudah disusun perlu diuji validitasnya. Uji validitas model dilakukan terhadap pohon-pohon di luar untuk penyusunan model dugaan volume pohon sebanyak 40 pohon, dengan menguji nilai simpangan agregatif (SA) dan simpangan rataan (SR). Hasil uji SA diperoleh nilai 2,I \% dan SR 6,2 \%. Menurut Marcelino (1966) dalam Siswanto dan Suyat (2004), selain kesalahan baku, tingkat ketelitian persamaan regresi bisa diukur dari nilai SA (< I \%) atau SR (< $10 \%)$. Selain nilai SA lebih dari $1 \%$, 
kemungkinan itu disebabkan dari nilai koefesien determinasi $\left(r^{2}\right)$ yang relatif rendah antara volume dan diameter sebesar $75,1 \%$. Berarti hampir $25 \%$ masih ada variabel lain yang berpengaruh terutama variasi tinggi pohon (T5) dan faktor lain. Jika menggunakan dua variabel (diameter dan tinggi pohon) dengan model yang sama (regresi linear berganda) diperoleh $r^{2}$ (R-square) 79,9\%. Berarti lebih dari $20 \%$ dipengaruhi oleh faktor selain diameter dan tinggi pohon. Faktor-faktor tersebut antara lain variasi tinggi batang utama, variasi jumlah cabang dan ranting pohon pada diameter ujung $5 \mathrm{~cm}$, sistem percabangan (mendatar, tegak lurus dan membentuk sudut tertentu), dan variasi panjang cabang dan ranting yang ikut menentukan besaran volume kayu Bidara Laut (Gambar I).

jika diperbandingkan dengan modelmodel bentuk regresi yang lain seperti pada Tabel 6, model regresi linear yang sudah disusun relatif lebih akurat untuk menduga volume pohon bidara laut. Disamping lebih sederhana (lebih mudah diaplikasikan), secara statistik mempunyai standar error yang relatif rendah dengan $R$-square yang relatif sama dan sangat signifikan pada 0,00 \% (Tabel 6).

Tabel 6. Model-model penduga volume pohon sampai diameter batang/cabang $5 \mathrm{~cm}$ Table 5. Models of tree volume estimation until diameter of $5 \mathrm{~cm}$ stem/branch)

\begin{tabular}{lllcc}
\hline No. & $\begin{array}{c}\text { Model regresi } \\
\text { (Regression } \\
\text { models) }\end{array}$ & \multicolumn{1}{c}{$\begin{array}{c}\text { Persamaan regresi } \\
\text { (Regression equations) }\end{array}$} & $\begin{array}{c}\text { Simpangan } \\
\text { baku (Std error) }\end{array}$ & R-square \\
\hline I. & Linear & $\mathrm{V}_{5}=-0,017+0,004 \mathrm{D}$ & 0,007 & $0,75 \mathrm{I}$ \\
2. & Logaritmik & $\mathrm{V}_{5}=-0,059+0,037 \log \mathrm{D}$ & 0,007 & 0,739 \\
3. & Kuadratik & $\mathrm{V}_{5}=-0,017+0,004 \mathrm{D}+0,00000006 \mathrm{D}^{2}$ & 0,007 & $0,75 \mathrm{I}$ \\
4. & Power & $\mathrm{V}_{5}=0,0002 \mathrm{D}$ & 0,350 & 0,788 \\
5. & Eksponen & $\mathrm{V}_{5}=0,004 \mathrm{e}^{0,193 \mathrm{D}}$ & 0,359 & 0,768 \\
\hline
\end{tabular}

\section{Model dugaan pada tinggi pohon pangkal tajuk}

Hasil uji dua variabel bebas (diameter dan tinggi pohon pangkal tajuk), disajikan pada Tabel 7. Pada Tabel tersebut, DurbinWatson dan perhitungannya, nilainya termasuk du $<$ d $<4$-du $(1,5888<2,107<$ 2,4II2) yaitu tidak ada autokorelasi. Oleh karena itu, penggunaan dua variabel untuk menyusun model regresi linear berganda dapat diperkenankan (hasil uji $F$ sangat signifikan). Berhubung adanya keterbatasan/kesulitan mengukur tinggi di lapangan, maka disusun juga model regresi dengan satu variabel diameter. Model persamaan regresi dengan satu variabel dibentuk sesuai dengan persyaratan, yaitu tidak ada autokorelasi (du $<\mathrm{d}<4$-du $=I, 5888<2, I 45<2,4 I I 2$ ), korelasi antar variabel (diameter dengan volume) sangat signifikan, dan hasil uji $F$ sangat signifikan sebagai petunjuk keabsahan penyusunan model linear. Kesalahan baku (SE) hasil perhitungan untuk dua variabel adalah $0,0062 /$ rerata volume $\times 100 \%=2,95 \%$, dan 3,10 \% untuk satu variabel. Berdasarkan hasil SE tersebut, terpenuhi persyaratan untuk menduga volume pohon. 
Tabel 7. Pengujian autokorelasi, tingkat korelasi dan linearitas model Table 7.Autocorrelation, correlation level and model linearity test

\begin{tabular}{|c|c|c|c|c|}
\hline \multirow{2}{*}{ Test } & \multicolumn{2}{|c|}{ Dua variabel (Two variables) } & \multicolumn{2}{|c|}{ Satu variabel (one variables) } \\
\hline & Statistic & Nilai Tabel/Sig. & Statistic & Nilai Tabel/Sig. \\
\hline Durbin-Watson & 2,107 & $\begin{array}{l}\mathrm{I}, 5888(\mathrm{dl}), \\
\mathrm{I}, 6898(\mathrm{du})\end{array}$ & 2,145 & $\begin{array}{l}\mathrm{I}, 6139(\mathrm{dl}), \\
\mathrm{I}, 6639(\mathrm{du})\end{array}$ \\
\hline $\begin{array}{l}\text { Koefesien } \\
\text { Korelasi (r) }\end{array}$ & 0,791 & 0,000 & 0,873 & 0,000 \\
\hline Anova $(F)$ & 65,175 & 0,000 & 109,344 & 0,000 \\
\hline Model regresi & $\begin{array}{r}V=-0,022+0,004 \\
\text { Dbh }+0,003 \mathrm{Tpt}\end{array}$ & $\begin{array}{r}0,0062 \\
\text { (std error) }\end{array}$ & $V=-0,017+0,004 \mathrm{Dbh}$ & $\begin{array}{r}0,0065 \\
\text { (std error) }\end{array}$ \\
\hline
\end{tabular}

Uji validitas model berikutnya adalah mencari nilai SA dan SR. Untuk model regresi satu variabel, diperoleh nilai $S A=$ $2,88 \%$ dan $\mathrm{SR}=4,19 \%$. Hanya nilai SR yang memenuhi syarat $(<10 \%)$. Pendugaan volume dengan dua variabel, nilai $R$-square $=76,2 \%$, berarti lebih hampir $24 \%$ masih ada variabel lain yang belum teridentifikasi dan berpengaruh. Volume pohon Bidara Laut sampai pangkal tajuk masih dipengaruhi oleh variasi tinggi batang utama, variasi jumlah cabang dan ranting sampai tinggi pohon pangkal tajuk.

Sama seperti hasil Tabel 6, model regresi linear yang disusun adalah model regresi terbaik untuk menduga volume bidara laut sampai tinggi pohon pada pangkal tajuk. Perbandingan dengan modelmodel bentuk regresi yang lain, persamaan regresi bentuk linear tetap yang terbaik. Simpangan baku dan $R$-square masingmasing model bentuk lain adalah model logaritmik 0,007 dan 0,763, model quadratik 0,007 dan 0,782 , model power 0,336 dan 0,809 , dan model eksponensial 0,343 dan 0,792 .

Untuk kepraktisan dan kesederhanaan model, dan kemudahan pengukuran di lapangan, penggunaan satu variabel bebas yaitu diameter batang pohon, telah banyak dihasilkan model regresi linear dan modifikasinya untuk menduga volume pohon berdiri. Untuk hasil pendugaan volume pohon bidara laut ini, berbeda hasilnya dengan model pendugaan volume pohon jenis-jenis lainnya. Hal tersebut dikarenakan kemungkinan adanya perbedaan bentuk batang, yaitu bentuk batang bidara laut tidak berbentuk taper (meruncing dari pangkal ke ujung batang).

Pada pengukuran per seksi pohon bidara laut di lapangan, diameter pangkal batang tidak selalu lebih besar daripada diameter batang berikutnya ke arah ujung batang. Sementara jenis-jenis lain kemungkinan berbentuk taper sehingga memperoleh model dugaan yang berbeda. Kebanyakan jenis-jenis lain menghasilkan model terbaik adalah model regresi power/geometrik $\mathrm{V}=\mathrm{a} \mathrm{D}^{\mathrm{b}}$ (di mana $: \mathrm{V}=$ volume pohon ; $D=d b h ; a, b=$ konstanta) dan model persamaan ini yang paling banyak digunakan (Muhdin, 2003), untuk membentuk tabel volume pohon berdiri (Tabel 8). 
Tabel 8. Model-model geometrik, pendugaan volume jenis-jenis pohon berdiri

Table 8. Geometric models, estimation of the volume of standing tree types

\begin{tabular}{|c|c|c|c|c|}
\hline No. & $\begin{array}{c}\text { Jenis dan Lokasi (Type and } \\
\text { location) }\end{array}$ & $\begin{array}{c}\text { Karakteristik } \\
\text { yang diukur } \\
\text { (Measured } \\
\text { characteristics) }\end{array}$ & $\begin{array}{l}\text { Model dugaan } \\
\text { (Model guess) }\end{array}$ & $\begin{array}{l}\text { Sumber } \\
\text { (Source) }\end{array}$ \\
\hline I. & $\begin{array}{l}\text { Rasamala (Altingea excelsa) di } \\
\text { Cianjur }\end{array}$ & $\begin{array}{l}\text { Diameter batang } \\
\text { setinggi dada (D) }\end{array}$ & $\begin{array}{l}\tilde{V}=0,000257 \\
D^{2,2563}\end{array}$ & $\begin{array}{l}\text { Siswanto dan } \\
\text { Wahjono, } 1996\end{array}$ \\
\hline 2. & $\begin{array}{l}\text { Karet (klon gabungan) di Sembawa } \\
\text { Sumatera Selatan }\end{array}$ & $\begin{array}{l}\text { Lilit batang } \\
\text { setinggi dada }(\mathrm{G})\end{array}$ & $V=0,5806 G^{0,5696}$ & Sahuri, 2017 \\
\hline 3. & $\begin{array}{l}\text { Sengon (Paraserianthes falcataria) } \\
\text { Karyasarim Leuwiliang, Kab Bogor }\end{array}$ & $\begin{array}{l}\text { Diameter batang } \\
\text { setinggi dada (D) }\end{array}$ & $\begin{array}{l}V=0,000213 \\
D^{2,37}\end{array}$ & $\begin{array}{l}\text { Ardelina et al, } \\
2015\end{array}$ \\
\hline 4. & $\begin{array}{l}\text { Nyawai (Ficus variegata Blume) di } \\
\text { Kalimantan Timur }\end{array}$ & $\begin{array}{l}\text { Diameter batang } \\
\text { setinggi dada (D) }\end{array}$ & $\begin{array}{l}V=0,00073 \\
D^{2,0051}\end{array}$ & $\begin{array}{l}\text { Qirom dan } \\
\text { Supriyadi, 20I3 }\end{array}$ \\
\hline
\end{tabular}

Perbedaan model persamaan regresi untuk menduga volume pohon bidara laut (model linear) dengan jenis-jenis pohon seperti pada Tabel 8 (model power/geometrik), dominan karena perbedaan karakteristik pohon seperti perbedaan bentuk batang utama. Disamping itu, perbedaan model ini juga dipengaruhi oleh beberapa faktor seperti metode pengukuran, alat yang digunakan, kondisi saat pengukuran dimensi pohon, dan lain-lain (Muhdin, 2003).. Bidara laut adalah sejenis perdu yaitu pohon dengan diameter rata-rata lebih kecil daripada jenis pohon pada umumnya. Jika kondisi memungkinkan, diameter batang dan tingginya dapat mencapai $30 \mathrm{~cm}$ dan $12 \mathrm{~m}$ (Heyne, 1987). Diameter (dbh) batang hasil pengamatan ini di TN Bali Barat adalah rata-rata kurang dari $10 \mathrm{~cm}$, pada hal belum pernah dilakukan eksploitasi dan penebangan secara legal. Angka bentuk dan taper pembentukan batang pohon juga kemungkinan berbeda antara jenis bidara laut dan jenis-pohon pohon kebanyakan. Besaran lingkar batang bidara laut di TN Bali Barat, kebanyakan diameter pangkal batang lebih kecil daripada dbh, dan sedikit selisihnya antara pangkal batang dan pangkal tajuk bidara laut. Sementara bentuk batang utama pada jenis-jenis di atas (jenis pohon), pada umumnya mempunyai angka bentuk kurang dari 0,7 (angka bentuk umum) dengan taper/bentuk batang yang mengerucut dari pangkal batang sampai pangkal tajuk (selisih diameter yang lebih besar daripada bidara laut).

\section{B. Potensi Kayu Bidara Laut}

Berdasarkan produktivitas untuk bahan baku pembuatan gelas songga, di Provinsi Bali jenis bidara laut hanya ditemukan di dalam Kawasan TN Bali Barat, termasuk Kecamatan Gerokgak Kabupaten Buleleng. Tepatnya berada di lokasi Banyuwedang, Teluk Terima dan Prapat Agung. Hasil sensus pada setiap lokasi, potensi kayu bidara laut di dalam kawasan TN Bali Barat disajikan pada Tabel 9. 
Tabel 9. Potensi kayu bidara laut pada setiap lokasi

Table 9. Potency of S. ligustrina wood on each lacation

\begin{tabular}{|c|c|c|c|c|c|}
\hline No & $\begin{array}{l}\text { Lokasi } \\
\text { (Location) }\end{array}$ & $\begin{array}{l}\text { DBH } \\
(\mathrm{cm})\end{array}$ & $\begin{array}{l}\text { BDS (Basal } \\
\text { area) }\left(\mathrm{m}^{2} / \mathrm{ha}\right)\end{array}$ & $\begin{array}{c}\text { Jumlah pohon (Tree } \\
\text { number)/ha* }\end{array}$ & $\begin{array}{c}\text { Potensi kayu (Wood } \\
\text { potency) per ha } \\
\left(\mathbf{m}^{3}\right)\end{array}$ \\
\hline $\mathrm{I}$. & Banyuwedang & $10,6 \pm 4,5$ & 2,3376 & 267 & $9,243 \pm 5,903$ \\
\hline 2. & Teluk Terima & $11,9 \pm 3,3$ & 1,2701 & 115 & $4,039 \pm 3,312$ \\
\hline 3. & Prapat Agung I & $8,2 \pm 2,1$ & 0,9302 & 177 & $3,532 \pm 1,379$ \\
\hline \multirow[t]{2}{*}{4.} & Prapat Agung II & $7,7 \pm 1,5$ & 0,8110 & 175 & $2,330 \pm 0,954$ \\
\hline & Rata-rata & $9,6 \pm 2,9$ & $\mathrm{I}, 3372$ & 184 & $4,786 \pm 2,887$ \\
\hline
\end{tabular}

Pada Tabel 9 dapat dilihat bahwa potensi kayu bidara laut terbesar terdapat di lokasi Banyuwedang, kemudian berturut-turut Teluk Terima, Prapat Agung I dan Prapat Agung II. Stok kayu bidara laut di Kawasan TN Bali Barat adalah $4,7 \mathrm{~m}^{3} /$ ha. Kelihatannya, potensi kayu untuk bahan baku gelas songga di dalam kawasan tersebut relatif sangat rendah. Akan tetapi, sortimen batang dengan ukuran diameter minimal $10 \mathrm{~cm}$ dan panjang $20 \mathrm{~cm}$ sudah dapat dimanfaatkan untuk produk gelas songga. Sebagai perbandingan, potensi bidara laut di Kabupaten Dompu dan Bima yang dari $10 \mathrm{~cm}$. selalu dieksploitasi untuk bahan baku gelas songga adalah I) Rerata diameter $13,1 \mathrm{~cm}$ dengan stok kayu 5, I m $\mathrm{m}^{3}$ (Dompu), 2) Di Kab Bima, rerata diameter $7,6 \mathrm{~cm}$ dengan stok kayu 2,I m (Susila, 2013 ; 20I6). Di Kawasan Banyuwedang dan Teluk Terima, lebih banyak tersedia bahan baku untuk gelas songga (Tabel 10). Kriteria pembagian tingkat tegakan seperti Tabel 10 ditentukan berdasarkan kriteria menurut Indriyanto (2006). Untuk bahan baku pembuatan gelas songga, kriteria batang pohon berdiameter tidak kurang

Tabel I0. Jumlah anakan, pancang, tiang dan pohon bidara laut pada setiap lokasi Table I0. Seedlings, saplings, poles and tree the sum on each location

\begin{tabular}{|c|c|c|c|c|c|}
\hline \multirow[b]{2}{*}{ No } & \multirow{2}{*}{$\begin{array}{l}\text { Lokasi } \\
\text { (Location) }\end{array}$} & \multicolumn{4}{|c|}{ S. ligustrina (N/ha) } \\
\hline & & $\begin{array}{c}\text { Semai } \\
\text { (Seedlings) }\end{array}$ & $\begin{array}{c}\text { Pancang }(\varnothing<10 \\
\mathrm{cm}) \text { (Saplings) }\end{array}$ & $\begin{array}{l}\text { Tiang ( } \varnothing 10- \\
20 \mathrm{~cm})(\text { Poles) }\end{array}$ & $\begin{array}{c}\text { Pohon }(\varnothing>20 \\
\mathrm{cm})(\text { Tree) }\end{array}$ \\
\hline $\mathrm{I}$. & Banyuwedang & 883 & 196 & 81 & 15 \\
\hline 2. & Teluk Terima & 1732 & 142 & 34 & 8 \\
\hline 3. & Prapat Agung I & 742 & 174 & 20 & 6 \\
\hline 4. & Prapat Agung II & 1269 & 177 & 18 & 4 \\
\hline & Rata-rata & 1156 & 172 & 38 & 8 \\
\hline
\end{tabular}

Jika diperbandingkan dengan potensi bidara laut di Sumbawa (Dompu dan Bima), kerapatan tegakan bidara laut di TN Bali Barat lebih besar, yaitu rata-rata lebih dari 1000 tanaman per hektar, sedangkan yang di Sumbawa hanya rata-rata lebih dari 100 tanaman per hektar. Perbedaan potensi ini disebabkan oleh perbedaan manajemen, yaitu 
yang di Bali Barat merupakan areal konservasi (Taman Nasional) yang dijaga kelestriannya dan yang di Sumbawa sebagian besar pada lahan di luar kawasan hutan yang merupakan areal sisa tebangan bidara laut. Dalam kondisi ekosistem yang lestari di Kawasan TN Bali Barat, sangat jarang dijumpai diameter batang pohon bidara laut antara $20 \mathrm{~cm}-25 \mathrm{~cm}$. Menurut Heyne (1987), bidara laut adalah tanaman kecil (perdu) dan dapat mencapai diameter batang sampai $30 \mathrm{~cm}$. Jadi ukuran diameter bidara laut yang relatif kecil memang disebabkan karena faktor genetik (Heyne, 1987) dan ditambah lagi dengan kondisi rapatnya tegakan dilokasi menyebabkan diameter bidara laut semakin tertekan. Jika dihitung, rata-rata kerapatan tegakan per lokasi (termasuk jenis lainnya) cukup tinggi, yaitu lebih dari 3000 pohon per hektar dengan jarak antar pohon rata-rata kurang dari $3 \mathrm{~m}$.

\section{Analisis Vegetasi}

Analisa vegetasi pada areal kawasan tempat tumbuh jenis bidara laut dimaksudkan untuk memperoleh data tentang komposisi jenis tanaman dan data kuantitatif mengenai sebaran, jumlah dan dominasi masing-masing jenis pada lokasi tersebut. Hasil analisis vegetasi disajikan pada Tabel II.

Tabel I I. Indeks Nilai Penting (INP) 10 jenis tingkat pohon di TN Bali Barat Table I I. The Importance Value Index of 10 species for tree stage at TN West Bali

\begin{tabular}{|c|c|c|c|c|c|}
\hline $\begin{array}{c}\text { Lokasi } \\
\text { (Location) }\end{array}$ & Jenis (Species) & $\begin{array}{l}\text { KR } \\
\text { (\%) }\end{array}$ & $\begin{array}{l}\text { FR } \\
\text { (\%) }\end{array}$ & $\begin{array}{l}\text { DR } \\
\text { (\%) }\end{array}$ & $\begin{array}{l}\text { INP } \\
\text { (\%) }\end{array}$ \\
\hline \multirow[t]{10}{*}{ Banyuwedang } & Bidara laut (Strychnos ligustrina) & 35,32 & 15,04 & 18,35 & 68,71 \\
\hline & Walikukun (Schoutenia ovata) & 19,58 & 15,04 & 24,14 & 58,76 \\
\hline & Mindi (Melia azedarach) & 14,95 & 15,04 & 12,73 & 42,71 \\
\hline & Putian (Croton argiratus) & 10,58 & 10,53 & 19,44 & 40,55 \\
\hline & Laban (Vitex pubescens) & 6,61 & 12,78 & 10,38 & 29,78 \\
\hline & Kapasan (Symplocos javanicum) & 7,94 & 9,77 & 8,65 & 26,36 \\
\hline & Suli (Bredelia monaica) & $\mathrm{I}, 72$ & 6,77 & $\mathrm{I}, 85$ & 10,33 \\
\hline & Tekih (Grewia koordersiana) & 1,32 & 3,76 & 2,15 & 7,23 \\
\hline & Pilang (Acacia leucophloea) & 0,66 & 3,01 & $\mathrm{I}, 28$ & 4,95 \\
\hline & Trenggayungan (Grewia sp.) & 0,40 & 2,26 & 0,29 & 2,94 \\
\hline \multirow[t]{10}{*}{ Teluk Terima } & Putian (Croton argiratus) & 47,75 & 16,07 & 49,28 & 101,63 \\
\hline & Bidara laut (Strychnos ligustrina) & 15,92 & 17,86 & 10,57 & 47,84 \\
\hline & Kapasan (Symplocos javanicum) & 14,88 & 14,29 & $|5,0|$ & 47,43 \\
\hline & Mindi (Melia azedarach) & 12,11 & 17,86 & 11,90 & 44,52 \\
\hline & Laban (Vitex pubescens) & 3,46 & 8,93 & 5,96 & 19,11 \\
\hline & Walikukun (Schoutenia ovata) & $\mathrm{I}, 73$ & 9,82 & 2,47 & 14,40 \\
\hline & Trenggayungan (Grewia sp.) & 2,08 & 5,36 & $\mathrm{I}, 70$ & 9,59 \\
\hline & Bunut (Ficus rigida) & 0,69 & 3,57 & $\mathrm{I}, 40$ & 5,81 \\
\hline & Serut (Sterblus asper) & 0,69 & 2,68 & 0,84 & 4,36 \\
\hline & Suli (Bredelia monaica) & 0,35 & 2,68 & 0,33 & 3,43 \\
\hline \multirow[t]{3}{*}{ Prapat Agung I } & Walikukun (Schoutenia ovata) & 26,09 & 14,49 & 31,15 & 71,73 \\
\hline & Putian (Croton argiratus) & 14,29 & 9,42 & 23,58 & 47,29 \\
\hline & Bidara laut (Strychnos ligustrina) & 22,05 & 14,49 & 6,70 & 43,24 \\
\hline
\end{tabular}




\begin{tabular}{clcccc}
\hline $\begin{array}{c}\text { Lokasi } \\
\text { (Location) }\end{array}$ & \multicolumn{1}{c}{$\begin{array}{c}\text { Jenis (Species) } \\
\text { Kindi (Melia azedarach) }\end{array}$} & $\begin{array}{c}\text { KR } \\
\mathbf{( \% )}\end{array}$ & $\begin{array}{c}\text { FR } \\
\mathbf{( \% )}\end{array}$ & $\begin{array}{c}\text { DR } \\
\text { (\%) }\end{array}$ & $\begin{array}{c}\text { INP } \\
\text { (\%) }\end{array}$ \\
\hline & Kapasan (Symplocos javanicum) & 13,98 & 12,32 & 13,24 & 39,53 \\
& Laban (Vitex pubescens) & 12,11 & 12,32 & 11,27 & 35,70 \\
& Suli (Bredelia monaica) & 2,48 & 8,70 & 4,13 & 15,31 \\
& Trenggayungan (Grewia sp.) & 2,80 & 7,97 & 2,91 & 13,68 \\
& Rukem (Flacaurtia rukam) & 2,17 & 7,25 & 1,81 & 11,23 \\
& Kapalan (Hoya disertifolia) & 0,93 & 4,35 & 1,19 & 6,47 \\
\hline Prapat Agung II & Walikukun (Schoutenia ovata) & 0,93 & 2,90 & 1,51 & 5,34 \\
& Putian (Croton argiratus) & 21,98 & 12,58 & 27,12 & 61,68 \\
& Bidara laut (Strychnos ligustrina) & 20,05 & 12,58 & 27,90 & 60,53 \\
& Mindi (Melia azedarach) & 19,23 & 12,58 & 5,22 & 37,03 \\
& Laban (Vitex pubescens) & 13,19 & 12,58 & 10,50 & 36,26 \\
& Hamer (Blocidia sp.) & 7,97 & 9,43 & 11,82 & 29,22 \\
& Suli (Bredelia monaica) & 4,95 & 10,69 & 4,65 & 20,28 \\
& Rukem (Flacaurtia rukam) & 3,57 & 9,43 & 3,78 & 16,79 \\
& Kapasan (Symplocos javanicum) & 4,40 & 6,92 & 4,54 & 15,86 \\
& Boni (Antidesma bunius) & 3,02 & 6,92 & 2,84 & 12,78 \\
& Trenggayungan (Grewia sp.) & 0,82 & 3,77 & 0,895 & 5,49 \\
& 0,82 & 2,52 & 0,747 & 4,09 \\
\hline
\end{tabular}

Keterangan (Remark) : KR = Kerapatan relatif (Relative dencity), FR = Frekuensi relatif

(Relative frequency), dan DR = dominasi relatif (Dominance relative)

Pada Tabel II dapat dilihat bahwa berdasarkan INP-nya, jenis-jenis seperti bidara laut (Strychnos ligustrina), walikukun (Shotenia ovata) dan putian (Croton argiratus) merupakan jenis-jenis yang dominan pada setiap lokasi yang di survey. Kecuali di lokasi Banyuwedang, dominasi ketiga jenis tersebut termasuk tiga INP tertinggi. Jenis dengan nilai INP yang tinggi dipandang lebih penting dari jenis lain yang mempunyai nilai INP lebih rendah. INP ini dapat digunakan sebagai salah satu parameter penentuan pentingnya suatu jenis secara ekologis dalam ekosistemnya (Lamprecht. 1989). Penentuan jenis prioritas untuk konservasi juga dapat menggunakan nilai INP sebagai salah satu parameternya (Simon, 2002). Oleh karena itu, jenis bidara laut mempunyai peran penting dalam ekosistemnya serta perlu dikonservasi untuk menjamin kelestariannya. Hasil survey ini, hampir sama dengan yang dilakukan Maharani et al (2015) di Kawasan TN Bali Barat, yaitu pada tingkat anakan dan pancang jenis bidara laut mendominasi, tingkat tiang ( $\mathrm{dbh} 10-20 \mathrm{~cm}$ ) berada pada urutan ketiga, dan pada tingkat pohon (dbh $>20 \mathrm{~cm}$ ) tidak ditemukan. Sementara hasil survey di Kabupaten Dompu, Sumbawa juga menunjukkan hasil yang relatif sama, yaitu pada tingkatan tiang, INP bidara laut termasuk rangking ketiga $(50,7 \%)$ setelah jenis S. ovata (63,5\%) dan Melia azedarach (52,7 \%), sedangkan pada tingkat pohon tidak ditemukan karena sebagian besar arealnya bekas tebangan (Setiawan dan Narendra, 2012). Total jenis tingkat pohon yang ditemukan di seluruh lokasi adalah 16 jenis, dengan masing-masing jumlah jenis yang ditemukan pada setiap lokasi adalah Banyuwedang 13 jenis, Teluk Terima II jenis, Prapat Agung I 15 jenis dan Prapat Agung II adalah II jenis. 


\section{KESIMPULAN DAN SARAN}

\section{A. Kesimpulan}

I. Model penduga volume kayu bidara laut sampai tinggi pohon diameter ujung batang/cabang $5 \mathrm{~cm}$ dan pangkal tajuk adalah $V=-0,017+0,004 \mathrm{dbh}$, dengan galat baku masing-masing 3,19 \% dan 3,10\%, dimana $\mathrm{V}=$ volume kayu ( $\mathrm{m}^{3} /$ pohon) dan $\mathrm{dbh}=$ diameter batang setinggi $\mathrm{dada} / \mathrm{I}, 30$ $\mathrm{m}(\mathrm{cm})$.

2. Potensi kayu bidara laut di kawasan TN Bali Barat adalah $4,7 \mathrm{~m}^{3} / \mathrm{ha}$, dengan lokasi sebaran mulai dari yang potensi tertinggi adalah Banyuwedang, Teluk Terima dan Prapat Agung. Kerapatan tegakan untuk setiap tingkat pertumbuhannya adalah tingkat anakan II56 tanaman/ha, tingkat pancang 172 tanaman/ha, tiangkat tiang 38 tanaman/ha dan tingkat pohon 8 tanaman/ha.

3. Indeks nilai penting tingkat pohon untuk tiga jenis tertinggi pada setiap lokasi di TN Bali Barat adalah di Banyuwedang I) Strychnos ligustrina 2) Schoutenia ovata 3)Melia azedarach, di Teluk Terima I) Croton argiratus 2) S.ligustrina 3) Symplocos javanicum, di Prapat Agung I I) S. ovata 2) C. argiratus 3) S.ligustrina, dan di Prapat Agung II I) S. ovata 2) C. argiratus 3) $S$. ligustrina.

\section{B. Saran}

I. Model penduga volume pohon ini hanya berlaku untuk kawasan TN Bali Barat dengan selang diameter pohon antara 5,0 $-15,0 \mathrm{~cm}$.

2. Untuk penggunaan model penduga volume ini di tempat lain, terlebih dahulu dilakukan validasi model.

3. Jenis bidara laut merupakan jenis penting (secara ekologi/INP relatif tinggi) dan bernilai ekonomis, menjadi salah satu prioritas pilihan untuk tanaman konservasi dan tanaman produksi sebagai bahan baku obat-obatan. Oleh karena itu, perlu mengembangkan jenis tersebut melalui teknik budidayanya.

\section{DAFTAR PUSTAKA}

Ardelina, A., T.Tiryana, Muhdin. 2015. Model Volume Pohon Sengon untuk Menilai Kehilangan Keuntungan Petani Hutan Rakyat. Jurnal Penelitian Hutan Tanaman Vol. 12 No. 2, Agustus 20I5, |3|-|39. Bogor

Arevalo C.B.M., T. A. Volk, E. Bevilacqua, and L. Abrahamson. 2007. Development and Validation of Aboveground Biomass Estimations for four Salix Clones in central New York. Biomass and Bioenergy 31: I-I 2.

Bappenas. 2006. Ringkasan: Kajian Strategi Pengembangan Potensi Hasil Hutan Non Kayu dan Jasa Lingkungan. Direktorat Kehutanan dan Konservasi Sumber Daya Air, Bappenas.

Brassard, B.W., H.Y.H. Chen, Y. Bergeron, and D.Pare. 20II. Coarse Root Biomass Allometric Equations for, and in the Boreal Forest of Ontario, Canada. Biomass and Bioenergy 35: 4189- 4196.

Bustomi, S, Harbagung, dan Suyat, 2005. Petunjuk Teknis Penyusunan Tabel Volume Pohon.Pusat Litbang Hutan Konservasi Alam. Bogor

Chen, X., P. Ender, M. Mitchell dan C. Wells. 2003. Regression with SAS. Publikasi online pada: www.ats.ucla.edu.

Dinas Kehutanan NTB, 2007. Statistik Dinas Kehutanan Provinsi Nusa Tenggara Barat Tahun 2006, Mataram

Dinas Lingkungan Hidup dan Kehutanan. 2017. Statistik Dinas Lingkungan Hidup dan Kehutanan Tahun 2016. Provinsi Nusa Tenggara Barat. Mataram 
Fachrul, M.F. 2007. Metode Sampling Bioekologi. Bumi Aksara. Jakarta.

Hasan, R.A., Nandini, R. Dan Wahyuni, N. 20II. Kajian Pemenfaatan Tanaman Bidara Laut (S Strychnos ligustrina BI) oleh Masyarakat di Kabupaten Dompu dan Buleleng. Prosiding Workshop, Sintesa Hasil Penelitian Hutan Tanaman Tahun 2010. HIm 353 - 358. Pusat Litbang Peningkatan Produktivitas Hutan. Bogor.

Heddy, S. 2012. Metode Analisis Vegetasi dan Komunitas. Divisi Buku Perguruan Tinggi, PT Raja Grafindo Persada. Jakarta.

Heyne, K. 1987. Tumbuhan Berguna Indonesia Jilid III. Badan Litbang Kehutanan. Departemen Kehutanan. Jakarta.

Husch, B. 1963. Forest Mensuration and Statistics. The Ronald Press Company. New York.

Indriyanto. 2006. Ekologi Hutan. Bumi Aksara. Jakarta.

Lamprecht, H. 1989. Silviculture in the

Tropics :Tropical Forest Ecosystems

and Their Tree Species-Possibilities

and Methods for their Long-term

Utilization, Eschborn, Germany.

Maharani, D, M.M.B. Utomo, R.Nandini. 2015. Ekologi Jenis Bidara Laut (Strychnos lucida R.Br.) di Kecamatan Gerokgak, Kabupaten Buleleng. Prosiding Seminar Nasional, "Peranan dan Strategi Kebijakan Pemanfaatan Hasil Hutan Bukan Kayu (HHBK) dalam Meningkatkan Daya Guna Kawasan (Hutan)”. Hal : 156 - 162. Fakultas Kehutanan Universitas Gajah Mada. Yogyakarta.

Muhdin. 2003. Dimensi Pohon dan Perkembangan Metode Pendugaan Volume Pohon. Pengantar Falsafah Sains. Program Pasca Sarjana, Institut
Pertanian Bogor. Bogor. www.rudyct.com/PPS702-ipb. Diakses |4-07-20|8

Nurgiyantoro, B., Gunawan, Marzuki. 2009. Statistik Terapan Untuk Penelitian IlmuIImu Sosial. Gajah Mada University Press. Yogyakarta.

Prodan, M. 1965. Forest Biometric. Perganon, Oxford. London

Qirom, M.A., Supriyadi. 2013. Model Pendugaan Volume Pohon Nyawai (Ficus variegata Blume) di Kalimantan Timur. Jurnal Penelitian Hutan Tanaman Vol.10 No.4, Desember 2013, 173 - 184. Bogor

Sahuri. 2017. Model Pendugaan Volume Pohon Karet saat Peremejaan di Sembawa, Sumatera Selatan. Jurnal Penelitian Hutan Tanaman Vol. 14 No. 2, Desember 2017, I39-I53. Bogor

Setiawan, O., Susila, IWW., dan Narendra, B. 2013. Potensi, Penyebaran, Karakteristik Tempat Tumbuh dan Implikasi Pengelolaan sebagai HHBK Potensial Sumber Bahan Obat di NTB dan Bali dalam Prosiding Seminar Nasional HHBK. Pusat Libang Peningkatan Produktivitas Hutan. Bogor.

Setiawan, O. and Narendra, B. 20I2. Ecology of $A$ Medicinal Tree Strychnos ligustrina Bl, in Dompu District, West Nusa Tenggara Province. Journal of Forestry Research, Forestry Research and Development Agency. Jakarta

Setiawan, $O$ dan T. Rostiwati. 2014. Bidara Laut Bidara Laut (Strychnos ligustrina Blume. syn. S. lucida R. Br): HHBK Potensial di NTB dan Bali. Buku Bidara Laut (Strychnos ligustrina Blume) syn. S. lucida R. Br: Sumber Bahan Obat Potensial di Nusa Tenggara Barat dan Bali. Forda Press, 2014. Bogor 
Simon, S. 2002. Inventory of woody species in Dindin Forest. Technical Report No. OI, IBCR/GTZ/FGRCP.

Simon, H. 2007. Metode Inventori Hutan. Pustaka Pelajar.Yogyakarta

Siswanto, B.E. dan D. Wahjono. 1996. Tabel isi pohon jenis Rasamala (Altingia excelsa Noronhae) di KPH Cianjur, Jawa Barat. Bul.Pen.Hutan No. 602:25-35. Pusat Litbang Hutan. Bogor

Soerianegara, I dan Indrawan, A. 1988. Ekologi Hutan Indonesia. Laboratorium Ekologi. Fakultas Kehutanan. Institut Pertanian Bogor, Bogor.

Subedi, M.R., and R.P. Sharma. 20 I2.Allometric Biomass Models for Bark of in Mid-Hill of Nepal. Biomass and Bioenergy 47: 44-49.

Sumadi, A., Nugroho, A.W., \& Rahman, T. (2010). Model penduga volume pohon pulai gading di Kabupaten Musi Rawas Sumatera Selatan. Jurnal Penelitian Hutan Tanaman, 7(2), I07-I I2. Bogor.

Susila, IWW. 2013. Potensi dan Model Dugaan Produk Kayu Songga (Strychnos ligustrina BI.) di Kabupaten Dompu dalam Prosiding Seminar Nasional HHBK. Pusat Libang Peningkatan Produktivitas Hutan. Bogor.
2016. Potensi dan Kajian Dugaan Produk Kayu Songga (Strychnos ligustrina BI.) di Kabupaten Bima dalam Prosiding Seminar Nasional Biodiversitas Savana Nusa Tenggara. HIm 64-75. Balai Litbang Lingkungan Hidup dan Kehutanan Kupang. Kupang.

Turski, M., C. Beker, K. Kazmierczak and T. Najgrakowski. 2008. Allometric Equations for Estimating the Mass and Volume of Fresh Assimilational Apparatus of Standing Scots Pine ( L.) Trees. Forest Ecology and Management (255):2678-2687.

Www.Flu.org.cn/en/download - 79. Htnl. 2008. Curve Expert 1.3. Diakses tanggal 7 September 2008.

www.spssstatistik.com, 2018. Cara Uji Autokorelasi dengan menggunakan SSPS. SSPS Statistik. Diakses, 8 Pebruari 2018

Zewdie, M., M. Olsson, and T.Verwijst. 2009.Aboveground Biomass Production and Allometric Relations of Labill. Coppice Plantations along a Chronosequence in the Central Highlands of Ethiopia. Biomass and Bioenergy 33: 421-428. 
Jurnal FALOAK Vol. 4 No.I April 2020: 39-56 